\title{
Physiological Comparison of Some Serum Biochemistry between Lactating and Non-Lactating Dairy Cows in Selected Dairy Farms of Dhaka District of Bangladesh
}

\author{
Sajibul Hasan ${ }^{1}$, Kamrul Islam², Mostafizer Rahman ${ }^{3}$ \\ ${ }^{1}$ Department of Preclinical Courses, Faculty of Veterinary and Animal Sciences, Gono University, Savar, Dhaka. \\ ${ }^{2}$ Department of Physiology, Faculty of Veterinary Science, Bangladesh Agricultural University, Mymensing-2202. \\ ${ }^{3}$ Department of Microbiology, Hajee Mohammad Danesh Science and Technology University, Dinajpur.
}

\begin{abstract}
The present study was carried out to investigate the physiological comparison of some serum biochemistry between lactating and non-lactating dairy cows in selected dairy farms of Dhaka district of Bangladesh. The aim of the current study was to evaluate the serum parameters like glucose, total protein, total cholesterol, calcium and phosphorus concentration and these parameters were measured by the serum analyzer for lactating $(n=50)$ and non-lactating $(n=50)$ dairy cattle which were selected from various selected dairy farms of Dhaka district. The results (mean \pm standard deviation) of the study showed that among the serum biochemical parameters total protein $(84.2 \pm 1.18 \mathrm{gm} / \mathrm{l})$ and total cholesterol $(156.36 \pm 3.41 \mathrm{mg} / \mathrm{dl})$ level in non-lactating cows were higher than the value of lactating cows as $(80.14 \pm 2.31 \mathrm{gm} / \mathrm{l})$ and $(138.21 \pm 1.21 \mathrm{mg} / \mathrm{dl})$. On the other hand, serum glucose, calcium and phosphorus level in lactating cows $(68.12 \pm 2.34 \mathrm{mg} / \mathrm{dl}),(12.06 \pm 3.21 \mathrm{mg} / \mathrm{dl})$ and $(8.30 \pm 0.20 \mathrm{mg} / \mathrm{dl})$ respectively were found higher than the non-lactating cows $(60.32 \pm 1.42 \mathrm{mg} / \mathrm{dl}),(10.48 \pm 5.60 \mathrm{mg} / \mathrm{dl})$ and $(6.31 \pm 0.12 \mathrm{mg} / \mathrm{dl})$. In case of parity-wise biochemical parameters were insignificant variation was found. It may be concluded that biochemical parameters variation present between lactating cow and non-lactating cow is important for interpretation of laboratory data and also for physiological diagnosis.
\end{abstract}

KEYWORDS: Serum biochemistry, lactating cow, non-lactating cow, dairy cow, parity.

\section{INTRODUCTION}

Blood biochemical attributes are important indicators of the metabolic activity in lactating animals (Karapehlivan et al., 2007). During lactation, secretary cells of mammary gland utilize $80 \%$ of the blood circulating metabolites for milk synthesis, depending on the speed of infiltration of precursors of milk compounds (i.e. free amino acids, glucose and fatty acids). All animals require minerals such as calcium $(\mathrm{Ca})$, magnesium $(\mathrm{Mg})$ and phosphorus $(\mathrm{P})$ for growth, reproduction and lactation which often affect specific requirements and serve as catalytic components of enzymes or regulate several mechanism involved just in pregnancy and lactation (Tanritanir et al., 2009 and Samardzija et al., 2011). Especially at the beginning of lactation, mobilization of Ca from bone and increased absorption from the gastrointestinal tract are required to re-establish homeostasis which have to react to a tremendous increase in demand for Ca (Liesegang, 2008 and Lohrenz et al., 2010). Milk, the outcome of various biochemical activities in mammary secretary cell is composed of fat, protein, carbohydrates, enzymes, vitamins and various minerals. The composition of milk is influenced by various factors, i.e., stage of lactation, lactation number, breed, feeding pattern, environmental and diseased condition of the udder (Brinez et al., 2003). The fat, protein and urea contents of milk vary according to stage of lactation. Fat content is high immediately after calving but soon begins to fall and continues to do so for 10 to 12 weeks, after which it tends to rise again until the end of the lactation (Chilliard et al., 2003, 2007). Approximately, 400 to 500 liters of blood circulate through mammary gland to produce one liter of milk (Fernandez and Hoeffler, 1998). There is a 2 to 6 folds increase in blood flow in the mammary gland starting 2 to 3 days prepartum. During lactation, the mammary gland secretory cells utilize $80 \%$ of the blood metabolites for milk synthesis depending on the infiltration of precursors of milk components like amino acids, glucose and fatty acids (Piccione et al., 2009). Hence, blood biochemical parameters including total protein, triglycerides, free fatty acids and urea are important indicators of the metabolic activity in lactating animals (Karapehlivan et al., 2007). Since the milk yield and composition varies across the length of lactation stage, it is, therefore, imperative, to study haemato-biochemical constituents during different stages i.e. early, mid and late stage of lactation. Although some variation has also been observed in the hematological parameters between breeds of farm animals (Tambuwal et al., 2002), in this regard, it may be difficult to formulate a universal blood 


\section{International Journal of Current Science Research and Review}

ISSN: 2581-8341

Volume 04 Issue 01 January 2021

DOI: 10.47191/ijcsrr/V4-i1-09, Impact Factor: 6.825

IJCSRR@ 2021

WwW.ijcsrr.org

metabolic profile test for animals. These differences have underlined the need to establish appropriate physiological baseline values for various breeds, farming and environmental condition of livestock. Therefore, the present study was undertaken to estimate the selected hematological nutritional status of crossbred dairy cows in Bangladesh in relation to age, parity and lactation.

\section{MATERIALS AND METHODS}

\section{Experimental area and duration:}

The experiment on physiological comparison of some serum biochemistry between lactating and non-lactating dairy cows in selected dairy farms of Dhaka district of Bangladesh was conducted for a period of 5 months (1th June to 31th October, 2020) in three selected dairy farms at savar area of Dhaka. The farms were selected based on population size greater than 50 crossbred (Holstein Friesian $\times$ Local) cows, house in tie-stall barn, standard ration feeding based on productive performance, milk yield more than or equal to ten liters per day, record keeping history, immunization against infectious disease and acceptance of farm to contribute in research work.

\section{Experimental population:}

The experimental population was 100 cross bred (HF $\times$ Local) healthy cows. In the farms, cows were in different age and production status, from which 50 lactating and 50 non lactating (dry) cows were selected based on parturition record for the first time, but not exceed for more than three times. Cows were further grouped into three categories on the basis of calving history (parity) of which parity-1 ( $n=35)$, parity-2 $(n=35)$ and parity-3 $(n=30)$. Some of the dry cows were pregnant, but they were not grouped further. All animals were fed both roughage and concentrates. Normal feeding habits of animals were observed during the research activities. All animals involved in this study were clinically healthy and to ensure this clinical history was reviewed with the farm manager through the examination of physical condition.

\section{Sample collection and processing:}

All blood samples were collected between 10 am to $12 \mathrm{pm}$ in order to standardize time. Blood samples were taken from jugular vein puncture with proper aseptic measures. About $5 \mathrm{ml}$ of blood was collected and kept in the vacationer tube without anticoagulant. The samples were transported to the Physiology laboratory under the Department of Veterinary and Animal Sciences at Gono University, Savar, Dhaka, Bangladesh for analysis. After coagulation, coagulated blood was centrifuged in 3000 RPM for 15 minutes. Serum was transferred to the Eppendorf tube by using micropipette. The obtained serum samples were stored in $-20^{\circ} \mathrm{C}$ for biochemical test in glucose, total protein, total cholesterol, calcium and phosphorus of blood serum were determined according to the biochemical analyzer manual (Humalyzer 3000, Germany R).

\section{Statistical analysis:}

Obtained laboratory data was stored in Microsoft Excell-2010 and imported to the software STAT/IC-13.0 for analysis. Descriptive statistical analysis was done to measure the mean, SEM, 95\% confidence interval (CI) and p value of different parameters. The arithmetic means $( \pm \mathrm{SE})$ serum biochemical parameters in different groups were calculated. In all cases the level of significance was determined at $\mathrm{p}<0.05)$.

\section{RESULTS AND DISCUSSION}

Findings for serum glucose, calcium and phosphorus level were within the reference range and their variations were insignificant (Table 1). Total protein levels in both lactating and dry cow were higher than the reference value, but the variation was insignificant between the lactating and dry group of cows. Serum cholesterol level was found lower in both groups than the standard value and variation between the groups was highly significant.

Table 1. Biochemical parameters (Mean \pm SD) in crossbred lactating cows and non-lactating cows.

\begin{tabular}{|c|c|c|c|c|c|}
\hline Parameters & $\begin{array}{c}\text { Glucose } \\
(\mathbf{m g} / \mathbf{d l})\end{array}$ & $\begin{array}{c}\text { Total protein } \\
(\mathbf{g m} / \mathbf{l})\end{array}$ & $\begin{array}{c}\text { Total cholesterol } \\
(\mathbf{m g} / \mathbf{d l})\end{array}$ & $\begin{array}{c}\text { Calcium } \\
(\mathbf{m g} / \mathbf{d l})\end{array}$ & $\begin{array}{c}\text { Phosphorus } \\
(\mathbf{m g} / \mathbf{d l})\end{array}$ \\
\hline Lactating cow & $68.12 \pm 2.34$ & $80.14 \pm 2.31$ & $138.21 \pm 1.21$ & $12.06 \pm 3.21$ & $8.30 \pm 0.20$ \\
\hline Non-Lactating cow & $60.32 \pm 1.42$ & $84.2 \pm 1.18$ & $156.36 \pm 3.41$ & $10.48 \pm 5.60$ & $6.31 \pm 0.12$ \\
\hline Reference value & $45-75$ & $67.4-74.6$ & $120-180$ & $9.7-12.4$ & $5.1-9.3$ \\
\hline
\end{tabular}

*Significant at $(\mathrm{p}<0.05)$ 


\section{International Journal of Current Science Research and Review}

ISSN: 2581-8341

Volume 04 Issue 01 January 2021

DOI: 10.47191/ijcsrr/V4-i1-09, Impact Factor: 6.825

IJCSRR @ 2021

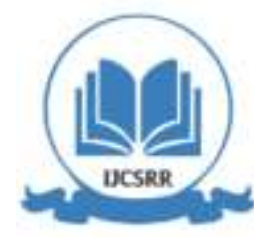

www.ijcsrr.org

The glucose level in lactating cows $(68.12 \pm 2.34 \mathrm{mg} / \mathrm{dl})$ was higher than the non-lactating cows $(60.32 \pm 1.42 \mathrm{mg} / \mathrm{dl})$ that $\mathrm{differ}$ insignificantly. Peterson et al., (1981) reported that glucose was higher in dry cows $(69.8 \pm 3.7 \mathrm{mg} / \mathrm{dl})$ than lactating cows $(65.2 \pm 1.7$ $\mathrm{mg} / \mathrm{dl})$. The blood glucose level is regarded as one of the indicators of energy status in the cow. The blood glucose level was higher in lactating cows this may be due to high energy diet feeding during lactation period and also for taking the extra amount of feed than the requirement of animal for milk production and maintenances. Other research by Cozziet al., (2011) in Holstein dairy cows reviled $58 \pm 0.40 \mathrm{mg} / \mathrm{dl}$. In a yearlong study of five upazilla namely Savar, Damray, Tongi, Shakhipur and Gazipur sadar of Bangladesh serum glucose level was found $(69.21 \pm 2.31 \mathrm{mg} / \mathrm{dl})$ in indigenous cattle (Hasan et al., 2013).

Total protein in serum in lactating and non-lactating cows were $(80.14 \pm 2.31 \mathrm{gm} / \mathrm{l})$ and $(84.2 \pm 1.18$ gm/l) respectively. The results of the current study were similar with Peterson et al., (1981) where total protein levels were reported to be higher in non-lactating cows $(90.23 \pm 0.23 \mathrm{gm} / \mathrm{l})$ than lactating cows $(70.73 \pm 0.09 \mathrm{gm} / \mathrm{l})$. Conversely, the total serum protein in lactation period $(60.32 \pm 0.60$ $\mathrm{gm} / \mathrm{l})$ was slightly higher than the dry period $(60.17 \pm 0.89 \mathrm{gm} / \mathrm{l})$ reported by Giuseppe et al., (2012). Serum total protein value in

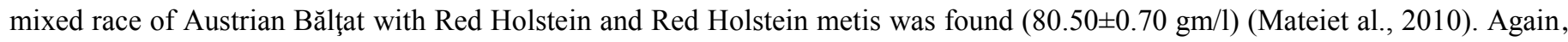
49.08 $\pm 8.16 \mathrm{~g} / \mathrm{l}$ value was found from twenty pregnant Freizian cows in Saudi Arabia (Al-Mujalli, 2008). In another study, the value of total protein in Holstein dairy cows was mentioned $82 \pm 6.10 \mathrm{~g} / \mathrm{l}$ by Cozziet al., (2011). Manzooret al., (2008) stated that, biochemical parameter of blood serum was higher in non-lactating cow than in lactating cows. There is a general modification in animals in serum proteins with advancing age and in the very old cows (Kaneko et al., 1997).

Total cholesterol in non-lactating cows $(156.36 \pm 3.41 \mathrm{mg} / \mathrm{dl})$ was higher than the lactating cows $(138.21 \pm 1.21 \mathrm{mg} / \mathrm{dl})$ with significant variation. Similarly Peterson et al., (1981) reported that total cholesterol was higher in dry cows (130.97 $\pm 0.14 \mathrm{mg} / \mathrm{dl})$ than lactating $(120.87 \pm 0.06 \mathrm{mg} / \mathrm{dl})$. In contrast total cholesterol value was found higher in lactating than non-lactating cows (Giuseppe et al., 2012). Serum total cholesterol parameter in mixed race with Austrian Blatt with Red Holstein and Red Holstein metis was found $(138.50 \pm 0.20 \mathrm{mg} / \mathrm{dl}$ ) (Mateiet al., 2010). In another study the overall mean value of total cholesterol was found $(145.13 \pm 6.33 \mathrm{mg} / \mathrm{dl})$ from twenty pregnant Friesian cows in Saudi Arabia (Al-Mujalli, 2008). In addition total cholesterol reference value $(137 \pm 2.50 \mathrm{mg} / \mathrm{dl})$ was reported by Cozziet al., (2011) in the Holstein dairy cows. Higher fat rich feed intake is responsible for higher cholesterol concentration in blood serum. Lower serum total cholesterol level in lactating cow is related to higher milk production of animal and depletion of cholesterol for maintaining milk production. The concentration of total cholesterol was influenced not only by the physiological condition of the animal, but also by nutrition (Kaneko et al., 1997).

According to parity, total protein level were found elevated than the reference value and the insignificant variation were shown among the different parity where lowest value was found in the third parity followed by first and second parity. On the other hand alike serum protein the serum cholesterol level was found lower in all three parities in which lowest value was found in parity two followed by parity three and parity one even though there variations were insignificant. However the serum glucose level was found in decreasing trend with insignificant variation in relation to parity proceed. Serum calcium and phosphorus level were followed almost similar trends and found higher at second parity (Table 2).

Table 2. Parity-wise changes of serum biochemical parameters (Mean \pm SD) in selected cows.

\begin{tabular}{|c|c|c|c|c|c|}
\hline Parameters & $\begin{array}{c}\text { Glucose } \\
(\mathbf{m g} / \mathbf{d l})\end{array}$ & $\begin{array}{c}\text { Total protein } \\
(\mathbf{g m} / \mathbf{l})\end{array}$ & $\begin{array}{c}\text { Total } \\
\text { cholesterol } \\
(\mathbf{m g} / \mathbf{d l})\end{array}$ & $\begin{array}{c}\text { Calcium } \\
(\mathbf{m g} / \mathbf{d l})\end{array}$ & $\begin{array}{c}\text { Phosphorus } \\
(\mathbf{m g} / \mathbf{d l})\end{array}$ \\
\hline Parity -1 & $62.48 \pm 2.45$ & $80.58 \pm 1.34$ & $152.34 \pm 5.82$ & $11.12 \pm 0.33$ & $7.80 \pm 0.28$ \\
\hline Parity -2 & $56.26 \pm 1.40$ & $76.48 \pm 1.88$ & $136.12 \pm 3.41$ & $11.58 \pm 0.53$ & $8.13 \pm 0.30$ \\
\hline Parity -3 & $52.23 \pm 3.20$ & $71.12 \pm 3.63$ & $128.70 \pm 4.80$ & $10.84 \pm 0.92$ & $7.11 \pm 0.32$ \\
\hline Reference value & $45-75$ & $67.4-74.6$ & $120-180$ & $9.7-12.4$ & $5.1-9.3$ \\
\hline
\end{tabular}

*Significant at $(\mathrm{p}<0.05)$

Within parity 1 serum total protein, total cholesterol and phosphorus level were higher in the non-lactating cows than the lactating whereas in parity 2 cholesterol and glucose level was higher in non-lactating cows. Conversely, in the case of third parity total protein, glucose, calcium and phosphorus level were found higher in lactating cows in comparison to the non-lactating cows. Overall variation within the parity were insignificant $(\mathrm{p}>0.05)$ (Table 3$)$. 


\section{International Journal of Current Science Research and Review}

ISSN: 2581-8341

Volume 04 Issue 01 January 2021

DOI: 10.47191/ijcsrr/V4-i1-09, Impact Factor: 6.825

IJCSRR@ 2021

WwW.ijcsrr.org

Table 3. Comparison of the serum biochemical parameters (Mean \pm SD) between lactating (L) and non-lactating (NL) crossbred dairy cows according to parity.

\begin{tabular}{|c|c|c|c|c|c|c|}
\hline \multicolumn{2}{|c|}{ Parameters } & $\begin{array}{c}\text { Glucose } \\
(\mathbf{m g} / \mathbf{d l})\end{array}$ & $\begin{array}{c}\text { Total protein } \\
(\mathbf{g m} / \mathbf{l})\end{array}$ & $\begin{array}{c}\text { Total } \\
\text { cholesterol } \\
(\mathbf{m g} / \mathbf{d l})\end{array}$ & $\begin{array}{c}\text { Calcium } \\
(\mathbf{m g} / \mathbf{d l})\end{array}$ & $\begin{array}{c}\text { Phosphorus } \\
(\mathbf{m g} / \mathbf{d l})\end{array}$ \\
\hline \multirow{2}{*}{ Parity- 1 } & Lactating & $69.04 \pm 8.60$ & $86.21 \pm 4.24$ & $148.46 \pm 3.12$ & $10.28 \pm 0.75$ & $6.08 \pm 0.45$ \\
\cline { 2 - 7 } & Non-lactating & $68.80 \pm 5.70$ & $82.46 \pm 2.41$ & $160.43 \pm 1.40$ & $9.45 \pm 0.98$ & $7.14 \pm 0.81$ \\
\hline Parity- 2 & Lactating & $60.32 \pm 4.30$ & $80.61 \pm 1.81$ & $142.70 \pm 3.81$ & $11.13 \pm 0.43$ & $6.30 \pm 0.58$ \\
\cline { 2 - 8 } & Non-lactating & $64.20 \pm 2.78$ & $77.50 \pm 1.52$ & $154.50 \pm 2.12$ & $10.32 \pm 0.72$ & $8.05 \pm 0.28$ \\
\hline Parity- 3 & Lactating & $65.08 \pm 8.19$ & $88.47 \pm 3.09$ & $172.32 \pm 4.30$ & $11.48 \pm 1.90$ & $6.31 \pm 0.51$ \\
\cline { 2 - 7 } & Non-lactating & $52.45 \pm 3.48$ & $78.03 \pm 5.32$ & $184.12 \pm 6.48$ & $10.26 \pm 1.24$ & $7.86 \pm 0.88$ \\
\hline
\end{tabular}

*Significant at $(\mathrm{p}<0.05)$

Calcium level was found slight higher $(12.06 \pm 3.21 \mathrm{mg} / \mathrm{dl})$ in lactating cows than the non-lactating (10.48 $\pm 5.60 \mathrm{mg} / \mathrm{dl})$. This result was supported by Peterson et al., (1981) where serum calcium in dry cows $(9.83 \pm 0.35 \mathrm{mg} / \mathrm{dl})$ was significantly lower than lactating cows $(10.02 \pm 0.14 \mathrm{mg} / \mathrm{dl})$. This result was in line with Giuseppe et al., (2012), where a level was found higher in lactation period $(8.03 \pm 0.80 \mathrm{mg} / \mathrm{dl})$ from the dry period $(7.83 \pm 0.76 \mathrm{mg} / \mathrm{dl})$. In a previous report serum calcium level was reported as $8.01 \pm 0.32$ $\mathrm{mg} / \mathrm{dl}$ in indigenous cow of Bangladesh (Mamun et al., 2013). Serum calcium decline at or soon after parturition might be an unavoidable mechanism in dairy cows, especially in aged cows (Horst et al., 1990; Goff et al., 1991) due to the expeditious loss of a by milk synthesis and less efficiency of calcium absorption by the intestinal transcellular pathway (Horst et al., 1990) and inactivation of the bone Care absorption pathway (Ramberg et al., 1970; Kamiya et al., 2005).

Phosphorus level in lactating and non-lactating cows were $(8.30 \pm 0.20 \mathrm{mg} / \mathrm{dl})$ and $(6.31 \pm 0.12 \mathrm{mg} / \mathrm{dl})$ respectively. According to Rowlands et al., (1974), phosphorus level was lower in dry cows than lactating. Peterson et al., (1981) also agreed the result of the present study where phosphorus high $(6.01 \pm 0.11 \mathrm{mg} / \mathrm{dl})$ in lactating than the dry period $(5.02 \pm 0.28 \mathrm{mg} / \mathrm{dl})$. Conversely Giuseppe et al., (2012) stated that, phosphorus level was higher in lactation than dry period. According to Patel et al., (1966) serum phosphorus level depends on climatic variation and the nature of the feed. Supplements of phosphorus in the diet have a very important role in blood phosphorus level of cow. The low level of dietary supplement of phosphorus is responsible for lower phosphorus level in serum (Kincaid et al., 2010). In a previous report serum phosphorus level was reported as $(5.90 \pm 0.40 \mathrm{mg} / \mathrm{dl}) \mathrm{in}$ indigenous cow of Bangladesh (Hasan et al., 2015).

\section{CONCLUSIONS}

The results found that there are some biochemical difference between lactating and non-lactating cows. Total protein and total cholesterol is higher in non-lactating cows than lactating cows, whereas glucose, calcium and phosphorus serum level is higher in lactating cows than non- lactating cows. This may be due to seasonal, geographic, dietary, breed or other residual effect that needs further study. Subtropical conditions of the present study might have played a role in the differences with other studies. Finally biochemical values are an efficient tool for evaluation of physiological status, metabolic disorders and management problems of the farm which have a great relation to health status of the animal and diagnosis of some pathos-physiological disorder in animals.

\section{ACKNOWLEDGEMENTS}

This work was supported in part by a grand in aid from the ministry of science and technology, the people's republic of Bangladesh. The authors are grateful to the respected farm members for their welcoming attitude during the study. The authors also thanks to Physiology laboratory of Gono University for the technical support of the research work. 
ISSN: 2581-8341

Volume 04 Issue 01 January 2021

DOI: 10.47191/ijcsrr/V4-i1-09, Impact Factor: 6.825

IJCSRR@ 2021

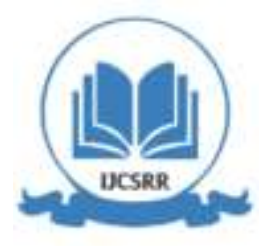

www.ijcsrr.org

\section{REFERENCES}

1. Botezatu, A., Vlagioiu, C., Codreanu, M., Oraşanu A. (2014) Biochemical and Hematological profile in cattle effective. Bulletin UASVM Veterinary Medicine 71(1):27-30.

2. Coroian Aurelia, Matea, C.T., Vodnar, D.C., Coroian, C.O. (2011) Bivolul românesc - Profilul metabolic și indicatori de calitate a laptelui, Editura Biofux, Cluj-Napoca.

3. Cozzi, G., Ravarotto. L., Gottardo, F., Stefani, A.L., Contiero, B., Moro, L., Brscic, M., Dalvit, P. (2011) Reference values for blood parameters in Holstein dairy cows: Effects of parity, stage of lactation, and season of production. J. Dairy Sci. 94:3895-3901.

4. Dhiman, T.R., Kleinmans, J., Tessmann, N.J., Radloff, H.D., Van Evert P., Satter LD. (1991) Effect of Dietary Forage:Grain Ratio on Blood Constituents in Dairy Cows. J Dairy Sci. 74:2691-2695.

5. Filipejová, T., Kováčik, J. (2009) Evaluation of selected biochemical parameters in blood plasma, urine and milk of dairy cows during the lactation period. Slovak J. Anim. Sci.1:8-12.

6. Hagawane, S.D., Shinde, S.B., Rajguru, D.N. (2009). Hematological and Blood Biochemical Profile in Lactating Buffaloes in and around Parbhani city. Veterinary World 2(12):467-469.

7. Imhasly, S., Naegeli, H., Baumann, S., von Bergen, M., Luch, A., Jungnickel, H., Potratz, S., Gerspach, C. (2014) Metabolomic biomarkers correlating with hepatic lipidosis in dairy cows. BMC Veterinary Research 2014(10):122.

8. Ingvartsen, K.L. (2006) Feeding- and management-related diseases in the transition cow - Physiological adaptations around calving and strategies to reduce feeding-related diseases. Animal Feed Science and Technology 126:175- 213.

9. Joźwik, A., Strzałkowska, N., Bagnicka, E., Grzybek, W., Krzyżewski, J., Poławska, E., Kołataj, A., Horbańczuk, J.O. (2012) Relationship between milk yield, stage of lactation, and some blood serum metabolic parameters of dairy cows. Czech J. Anim. Sci. 57:353-360.

10. Khaled, N.F., Illek, J., Gajdusek, S. (1999) Interactions between nutrition, blood metabolic profile and milk composition in dairy goats. Acta Vet. Brno 68:253-258.

11. Lumsden, J.H., Mullen, K., Rowe, R. (1980) Hematology and Biochemistry Reference Values for Female Holstein Cattle. Can. J. Comp. Med. 44:24-31.

12. Mazzullo, G., Rifici, C., Cammarata, F., Caccamo, G., Rizzo, M., Piccione, G. (2014) Effect of different environmental conditions on some hematological parameters in cow. Ann. Anim. Sci. Vol. 14 No. 4:947-954.

13. Nath, H.C. (2005) Serum cholesterol and protein in pre, peri and postpartum cows. Indian Vet J 82:519-521.

14. Payne, J.M., Dew, S.M., Manston, R.I., Margaret, F. (1970) The use of a metabolic profile test in dairy herds. Veterinary Record 87:150-158.

15. Pysera, B., Opalka, A. (2000) The effect of gestation of dairy cows on lipid and lipoprotein patterns and composition in serum during winter and summer feeding. J Anim Feed Sci 9:411-424.

16. Quiroz-Rocha, G.F., Leblanc, S.J., Duffield, T.F., Wood, D., Leslie, K.E., Jacobs, R.M. (2009) Reference limits for biochemical and hematological analytes of dairy cows one week before and one week after parturition. Can Vet $\mathrm{J} 50$ (4):383-388.

17. Radkowska, I., Herbut, E. (2014) Hematological and biochemical blood parameters in dairy cows depending on the management system. Animal Science Papers and Reports 32:317-325.

18. Roland, L., Drillich, M., Iwersen, M. (2014) Hematology as a diagnostic tool in bovine medicine. Journal of Veterinary Diagnostic Investigation Vol. 26(5):592-598.

19. Rowland, G.J. (1975) Relationship between stage of lactation and pregnancy and blood composition in a herd of dairy cow and the influences of seasonal changes in management of these relationships. J Dairy Res 42:349- 362.

20. Ruginosu, E., Creangă, Ş., Sofronie, M., Mălăncuş, R., Boghian, V., Solcan, G.h. (2011). The biochemical profile in cow with reproductive disorders. Cercetări Agronomice în Moldova Vol. XLIV No.2 (146).

21. Sabasthin, A., Kumar, V.G., Nandi, S., Murthy, V.C. (2012) Blood hematological and biochemical parameters in normal cycling, pregnant and repeat breeding buffaloes (Bubalus bubalis) maintained in isothermic and is nutritional conditions. Asian Pacific Journal of Reproduction 1(2):117-119.

22. Seifi, H.A., Gorji-Dooz, M., Mohri, M., Dalir-Naghadeh, B., Farzaneh, N. (2007) Variations of energy-related biochemical metabolites during transition period in dairy cows. Comparative Clinical Pathology 16, Issue 4:253- 258. 


\section{International Journal of Current Science Research and Review}

ISSN: 2581-8341

Volume 04 Issue 01 January 2021

DOI: 10.47191/ijcsrr/V4-i1-09, Impact Factor: 6.825

IJCSRR @ 2021

Www.ijcsrr.org

23. Van Saun, R.J. (2010) Blood Profiles as Indicators of Nutritional Status. Advances in Dairy Technology 12: $401-410$.

24. Wiziri, M.A., Ribadu, A.Y., Sivachelvan, N. (2010) Changes in the serum proteins, hematological and some serum Biochemical and Hematological profiles in the gestation period in the Sahel goats. Veterinarski arhiv 80(2):215-224.

Cite this Article: Sajibul Hasan, Kamrul Islam, Mostafizer Rahman (2021). Physiological Comparison of Some Serum Biochemistry between Lactating and Non-Lactating Dairy Cows in Selected Dairy Farms of Dhaka District of Bangladesh. International Journal of Current Science Research and Review, 4(01), 53-58 